\title{
Efficient use of Resources by Wheat-Lucerne Mixed Cropping
}

\author{
A. S. Patel, M. S. Dabhi*, K. J. Vihol, K. I. Patel, M. D. Patel and S. I. Patel \\ Wheat Research Station, S. D. Agricultural University, Vijapur-384 570, India \\ *Corresponding author
}

\begin{abstract}
A B S T R A C T
\section{Keywords}

Wheat, Lucerne, Mixed cropping, LER, Monetary advantage

\section{Article Info}

Accepted:

26 July 2020

Available Online:

10 August 2020

A field experiment on agro-economic relationship of component crops in wheatlucerne mixed cropping system was conducted at wheat research station, vijapur during rabi and summer seasons of 2014-15 to 2016-17 to study the effects of mixed cropping system on yield, yield components of wheat and lucerne and efficiency of resource utilization. Mixed cropping treatments registered higher wheat equivalent yield as compared to sole cropping treatments. Further results revealed that the highest (1.83) land equivalent ratio (LER) and $\mathrm{B}: \mathrm{C}$ ratio (1:2.13) for total grain and straw yields were observed under wheat @ $120 \mathrm{~kg} / \mathrm{ha}$ (Broadcasting) + lucerne @ $12 \mathrm{~kg} / \mathrm{ha}$ (Broadcasting), while different treatments failed to exert any significant influence on growth and yield attributes of wheat except test weight.
\end{abstract}

\section{Introduction}

Wheat is the second most important staple food crop of India. Intensive cropping system depletes nutrients from the soil. Therefore, it is necessary to provide sufficient amount of nutrients from outside in the form of organic or inorganic way. Besides, this suitable cropping system e.g. mix cropping is an alternative which add plant nutrients in the soil for realizing maximum yield and sustain soil health. Mix cropping of wheat-lucerne has immense importance in North Gujarat, where the per capita land holding is very low. $\mathrm{N}$-fixation by lucerne in soil will help in increasing yield of wheat and succeeding crop. Lucerne not increases the nutritive value of wheat fodder but also helps in sustaining soil productivity. Intercropping of cereals with legumes has been popular in rainfed areas due to its low cost of production and high monetary returns to the farmers (Ofori and Stern, 1987), improving yield stability, socio-economic status and some other advantages (Willey, 1979). Feasibility of wheat and lucerne as mixed cropping during winter season in north Gujarat is required to be tested as most of the farmers grown wheat crop and hiring the live stock as mix farming within small land holding. Thus, the aim of the study is to determine the best treatment combination, its economic and efficiency of resource utilization by determining land equivalent ratio (LER). Considering the above 
facts, this experiment was planned to know the efficient use of resources by wheatlucerne mixed cropping by interacting the sowing methods and varying levels of lucerne seed rate.

\section{Materials and Methods}

A field experiment was conducted during rabi and summer seasons of 2014-15 to 2016-17. The experimental soil was sandy loam with $\mathrm{pH}$ 7.7, electrical conductivity (EC) 0.32 $\mathrm{dS} / \mathrm{m}$, organic carbon $0.32 \%$ with available $159 \mathrm{~kg} \mathrm{ha}^{-1} \mathrm{~N}$ and $38.2 \mathrm{~kg} \mathrm{ha}^{-1} \mathrm{P}_{2} \mathrm{O}_{5}$. The experiment was laid out in Randomized Block design with four replications. The treatments composting: $\mathrm{T}_{1}$ : Wheat @ $120 \mathrm{~kg} \mathrm{ha}^{-1}$ (Broadcasting) + Lucerne @ $8 \mathrm{~kg} \mathrm{ha}^{-1}$ (Broadcasting), $\mathrm{T}_{2}$ : Wheat @ $120 \mathrm{~kg} \mathrm{ha}^{-1}$ (Broadcasting) + Lucerne @ $12 \mathrm{~kg} \mathrm{ha}^{-1}$

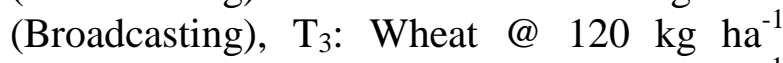
(Line sowing) + Lucerne @8 kg ha ${ }^{-1}$ (Broadcasting), T : Wheat @ $120 \mathrm{~kg} \mathrm{ha}^{-1}$ (Line sowing) + Lucerne @12 kg ha ${ }^{-1}$ (Broadcasting), T5: Wheat sole @ $120 \mathrm{~kg} \mathrm{ha}^{-1}$ (Line sowing), $\mathrm{T}_{6}$ : Lucerne sole @ $15 \mathrm{~kg} \mathrm{ha}^{-1}$ (Broadcasting). Line sowing of wheat under treatments $\mathrm{T}_{3}, \mathrm{~T}_{4} \& \mathrm{~T}_{5}$ was carried out at 22.5 $\mathrm{cm}$ spacing between two rows, while, wheat broadcast under treatments $\mathrm{T}_{1} \& \mathrm{~T}_{2}$. Lucerne was broadcasted under all the treatments at the time of wheat sowing. FYM @ 10 tone ha ${ }^{1}$ was applied in kharif 2014 as a common dose.

Recommended fertilizer dose i.e. 120:60:00 NPK kg ha ${ }^{-1}$ was applied to wheat sole and wheat + lucerne mix cropping treatments during all the experimental years, while, 20:80:00 NPK kg ha ${ }^{-1}$ was applied to lucerne sole treatment. Lucerne crop was supplemented with $40 \mathrm{~kg} \mathrm{~N}^{-1}$ for seed production after wheat harvest. Seven Irrigations (including sowing irrigation) were applied during wheat crop period and four irrigations applied to lucerne crop at 7, 22, 42 and 60 days after harvest of wheat for lucerne seed production. The experiment was sown on $15^{\text {th }}, 24^{\text {th }}$ and $16^{\text {th }}$ November in 2014,2015 and 2016, respectively. In order to evaluate the competitive effects between wheat and lucerne crops and to determine its performance as mix and sole crop, yield and yield attributing characters along with economics for each treatment were recorded. LER values were calculated according to Willey (1979) using the following formula:

LER $=$ LER $($ wheat $)+$ LER (lucerne $)=($ Ywm / Yws $)+($ Ylm / Yls $)$

Where, Yws and Yls are the yields of wheat and lucerne as sole crop, and Ywm and Ylm are the yields of wheat and lucerne as mixed crop, respectively.

\section{Results and Discussion}

\section{Growth and yield attributes of wheat}

Poled data in Table 1 indicated that different treatments failed to exert any significant influence on growth and yield attributes of wheat except its test weight.

\section{Grains/spike}

The effect of different treatment was nonsignificant on number of grains/spike. However, numerically higher (39) number of grains were recorded under $\mathrm{T}_{4}$ (Wheat @ 120 kg/ha (Line sowing) + Lucerne @ 12 kg/ha (Broadcasting).

\section{Spikes $/ \mathrm{m}^{2}$ (nos.)}

Effect of different treatment was nonsignificant on no of spikes $/ \mathrm{m}^{2}$ of wheat. However, $\mathrm{T}_{1}$ (Wheat @ $120 \mathrm{Kg} / \mathrm{ha}$ (Broadcasting) + Lucerne @ $8 \mathrm{Kg} / \mathrm{ha}$ (Broadcasting) recorded numerically higher tillers $/ \mathrm{m}^{2}$ (414). 


\section{Spike length (cm)}

Spike length $(\mathrm{cm})$ of wheat was unaffected under different treatments. However, numerically higher Spike length recorded in $\mathrm{T}_{1} \mathrm{~T}_{2}$ and $\mathrm{T}_{4}(8.2 \mathrm{~cm})$.

\section{0 grain weight $(g)$}

1000 grain weight was significantly affected by different treatments. Result revealed that significantly the highest 1000 grain weight (48.1 g) was recorded under $\mathrm{T}_{2}$ (Wheat @ 120 kg/ha (Broadcasting)+Lucerne @ 12 kg/ha (Broadcasting).

It might be due to efficient utilization of nitrogen which was additionally fixed by lucerne and effective utilization of resources like nutrients and moisture which affected the grain filling and ultimately resulted into higher test weight. This finding is in accordance with the findings of Ahmad, (1989), Singh, (1994), Akter, et al., (2004) and Çiftçi and Ülker (2005).

\section{Wheat grain \& straw yield (q/ha)}

Pooled data in Table 2 indicated that $\mathrm{T}_{2}$ (Wheat@120 kg/ha (Broadcasting) + Lucerne @ 12 kg/ha (Broadcasting) recorded significantly the highest wheat grain yield (46.82 q/ha) and straw (wheat + lucerne mix) yield (67.62 q/ha).

Due to broadcasting of wheat and lucerne, land and other resources were efficiently used by plant roots which reflect on higher test wt. $(48.1 \mathrm{~g})$ of wheat and ultimately the highest wheat grain yield as compare to rest of the treatments. Seed rate of wheat was equal for all the treatments, but for lucerne it was at variance. If lucerne seed rate increases, the number of lucerne plants also increase as compare to lower seed rate which reflects in the highest straw (wheat + lucerne mix) yield.
These findings are in accordance with Ahmad, (1989), Singh, (1994), Akter, et al., (2004), Çiftçi and Ülker, (2005) and Yagmur and Kaydan, (2006).

\section{Lucerne seed \& straw yield (q/ha)}

Lucerne seed yield was found significant on pooled basis (Table 2). Treatment $\mathrm{T}_{2}$ (Wheat @ $120 \mathrm{Kg} / \mathrm{ha}$ (Broadcasting)+Lucerne @ 12 $\mathrm{Kg} / \mathrm{ha}$ (Broadcasting) recorded significantly higher lucerne grain yield $(1.83 \mathrm{q} / \mathrm{ha})$. Though remaining all the treatment were at par with treatment $T_{2}$ except $T_{3}$ with respect to the lucerne seed yield. There was no significant difference found among the treatments for lucerne straw yield. However, the treatment $\mathrm{T}_{6}$ (Sole lucerne @ $15 \mathrm{~kg} / \mathrm{ha}$ broadcasting) produced higher lucerne straw yield (46.26 $\mathrm{q} / \mathrm{ha})$ followed by treatments $\mathrm{T}_{2}(44.47 \mathrm{q} / \mathrm{ha})$ and $\mathrm{T}_{4}(43.04 \mathrm{q} / \mathrm{ha})$, respectively.

It might be due to higher lucerne seed rate and increase number of tillers per plant after every cut of lucerne for green fodder purpose. This finding was in accordance with Ahmad, (1989), Singh, (1994), Akter, et al., (2004), Çiftçi and Ülker, (2005) and Yagmur and Kaydan, (2006).

\section{Wheat equivalent yield (q/ha)}

Wheat equivalent yield was significantly influenced under mix cropping treatments. Significantly the highest wheat equivalent yield $(79.22 \mathrm{q} / \mathrm{ha})$ was recorded with $\mathrm{T}_{2}$ (sowing of wheat @120 kg/ha and lucerne @ $12 \mathrm{~kg} / \mathrm{ha}$ by adopting broadcasting method).

Among mix cropping treatments sowing of wheat in the line keeping $22.5 \mathrm{~cm}$ distance between two row and broadcasting of lucerne (a) $8 \mathrm{~kg} / \mathrm{ha}$ produced the lowest wheat equivalent yield (68.02 q/ha) but it was at par when Lucerne broadcasted @ $12 \mathrm{~kg} / \mathrm{ha}$. 
Table.1 Effect of mixed cropping treatments on growth and yield attributes of wheat (Pooled data of three years)

\begin{tabular}{|c|c|c|c|c|c|c|c|c|}
\hline Treatment & $\begin{array}{c}\text { Plant } \\
\text { stand } / \mathbf{m}^{2}\end{array}$ & $\begin{array}{c}\text { Plant } \\
\text { height }(\mathrm{cm})\end{array}$ & $\begin{array}{c}\text { Spike } \\
\text { length }(\mathbf{c m})\end{array}$ & $\begin{array}{l}\text { No. of grains/ } \\
\text { spike }\end{array}$ & $\begin{array}{l}\text { Heading } \\
\text { days }\end{array}$ & $\begin{array}{l}\text { Maturity } \\
\text { days }\end{array}$ & $\begin{array}{l}\text { Spikes } / \mathbf{m}^{2} \\
\text { (No.) }\end{array}$ & $\begin{array}{l}1000 \text { grain } \\
\text { wt. (g) }\end{array}$ \\
\hline $\begin{array}{l}\mathrm{T}_{1} \text { : Wheat @ } 120 \mathrm{Kg} / \mathrm{ha} \text { (Broadcasting) + } \\
\text { Lucerne @8 Kg/ha (Broadcasting) }\end{array}$ & 365 & 84.0 & 8.2 & 38 & 61 & 103 & 414 & 46.0 \\
\hline $\begin{array}{l}\mathrm{T}_{2}: \text { Wheat @ } 120 \mathrm{Kg} / \mathrm{ha} \text { (Broadcasting) + } \\
\text { Lucerne @ } 12 \mathrm{Kg} / \mathrm{ha} \text { (Broadcasting) }\end{array}$ & 354 & 84.4 & 8.2 & 38 & 60 & 103 & 409 & 48.1 \\
\hline $\begin{array}{l}\mathrm{T}_{3}: \text { Wheat @ } 120 \mathrm{Kg} / \mathrm{ha} \text { Line sowing) + } \\
\text { Lucerne @8 Kg/ha Broadcasting) }\end{array}$ & 345 & 85.0 & 8.0 & 38 & 60 & 102 & 409 & 44.9 \\
\hline $\begin{array}{l}\mathrm{T}_{4}: \text { Wheat @ } 120 \mathrm{Kg} / \mathrm{ha} \text { (Line sowing) + } \\
\text { Lucerne @ } 12 \mathrm{Kg} / \mathrm{ha} \text { (Broadcasting) }\end{array}$ & 361 & 85.9 & 8.2 & 39 & 60 & 103 & 398 & 46.0 \\
\hline $\mathrm{T}_{5}$ :Wheat @ sole $120 \mathrm{Kg} / \mathrm{ha}$ (Line sowing) & 362 & 85.1 & 8.1 & 38 & 60 & 103 & 406 & 45.1 \\
\hline S.Em. \pm & 9.62 & 0.91 & 0.08 & 1.01 & 0.27 & 0.37 & 9.83 & 0.43 \\
\hline CD at $5 \%$ & NS & NS & NS & NS & NS & NS & NS & 1.2 \\
\hline CV\% & 9.33 & 3.74 & 3.64 & 9.19 & 1.56 & 1.24 & 8.37 & 3.25 \\
\hline
\end{tabular}

Table.2 Effect of mixed cropping on yield of wheat, lucerne, wheat equivalent yield, LER and economics (Pooled data of three years)

\begin{tabular}{|c|c|c|c|c|c|c|c|c|c|}
\hline \multirow[t]{2}{*}{ Treatment } & \multicolumn{2}{|c|}{ Wheat yield (q/ha) } & \multicolumn{2}{|c|}{$\begin{array}{l}\text { Lucerne yield } \\
\text { (q/ha) }\end{array}$} & \multirow{2}{*}{$\begin{array}{c}\text { Wheat } \\
\text { equivalent } \\
\text { yield } \\
\text { (q/ha) }\end{array}$} & \multirow[t]{2}{*}{ LER } & \multirow{2}{*}{$\begin{array}{c}\text { Cost of } \\
\text { cultivation } \\
\text { Rs./ha }\end{array}$} & \multirow{2}{*}{$\begin{array}{c}\text { Net } \\
\text { return } \\
\text { Rs./ha }\end{array}$} & \multirow[t]{2}{*}{ BCR } \\
\hline & Grain & $\begin{array}{l}\text { Straw (wheat }+ \\
\text { lucerne) }\end{array}$ & Grain & Straw & & & & & \\
\hline $\begin{array}{l}\mathrm{T}_{1} \text { : Wheat @ } 120 \mathrm{Kg} / \mathrm{ha} \text { (Broadcasting) + } \\
\text { Lucerne @8 Kg/ha (Broadcasting) }\end{array}$ & 41.77 & 58.88 & 1.73 & 44.15 & 72.53 & 1.67 & 63128 & 63800 & $1: 2.01$ \\
\hline $\begin{array}{l}\mathrm{T}_{2}: \text { Wheat @ } 120 \mathrm{Kg} / \mathrm{ha} \text { (Broadcasting) + } \\
\text { Lucerne@ } 12 \mathrm{Kg} / \mathrm{ha} \text { (Broadcasting) }\end{array}$ & 46.82 & 67.62 & 1.83 & 44.47 & 79.22 & 1.83 & 65064 & 73571 & $1: 2.13$ \\
\hline $\begin{array}{l}\text { T}_{3} \text { : Wheat @ } 120 \mathrm{Kg} / \mathrm{ha} \text { (Line sowing) + } \\
\text { Lucerne @ } 8 \mathrm{Kg} / \mathrm{ha} \text { (Broadcasting) }\end{array}$ & 40.96 & 59.69 & 1.47 & 39.68 & 68.02 & 1.56 & 63793 & 55242 & $1: 1.87$ \\
\hline $\begin{array}{l}\mathrm{T}_{4}: \text { Wheat @ } 120 \mathrm{Kg} / \mathrm{ha} \text { (Line sowing) + } \\
\text { Lucerne @ } 12 \mathrm{Kg} / \mathrm{ha} \text { (Broadcasting) }\end{array}$ & 39.42 & 58.73 & 1.66 & 43.04 & 69.14 & 1.59 & 65729 & 55266 & $1: 1.84$ \\
\hline$T_{5}:$ Wheat @ sole 120 Kg/ha (Line sowing) & 41.39 & 53.15 & - & - & 44.42 & - & 43145 & 34590 & $1: 1.80$ \\
\hline $\mathrm{T}_{6}$ : Lucerne sole @ $15 \mathrm{Kg} / \mathrm{ha}$ (Broadcasting) & - & - & 1.63 & 46.26 & 45.34 & - & 55741 & 23604 & $1: 1.42$ \\
\hline S.Em. \pm & 1.00 & 1.55 & 0.08 & 1.64 & 1.38 & 0.03 & - & - & - \\
\hline CD at $5 \%$ & 2.83 & 4.42 & 0.22 & NS & 3.91 & 0.09 & - & - & - \\
\hline CV\% & 8.20 & 9.03 & 15.85 & 13.04 & 7.56 & 6.76 & - & - & - \\
\hline
\end{tabular}


It might be due to efficient utilization of resource i.e. land, water and nutrients which increased wheat as well as lucerne seed yield. The difference amongst the treatments for wheat + lucerne straw yield was due to the difference of seed rate of lucerne as per the treatments. These results are in line with the findings of Willey (1979), Ofori et al., (1987) and Chen et al., (2004).

\section{Land Equivalent Ratio}

Significantly the highest LER (1.83) value was obtained when wheat and lucerne crop broadcasted @120 \& 12 kg/ha, respectively. This result was obtained due to higher wheat grain and straw (wheat + lucerne) yield as well as lucerne seed production by efficient utilization of resources as compare to sole (wheat \& lucerne) crop. The result is collaborative with the findings of Ofori \& Stern, (1987), Willey (1979), Caballero et al., (1995) and Dhima et al., (2007).

\section{Economics}

Economics was calculated on the basis of wheat equivalent yield. Wheat and lucerne mix cropping treatments rewarded higher net return and benefit:cost ratio as compared to its sole sowing. Among all the treatments, sowing of wheat @ $120 \mathrm{~kg} / \mathrm{ha}$ along with lucerne @ 12 kg/ha through broadcasting method $\mathrm{T}_{2}$ recorded the highest net return (Rs. 73571/-) and benefit: cost ratio (1:2.13) followed by treatment $\mathrm{T}_{1}$ (net return Rs. 63800/- \& 1:2.01 BCR). It might be due to increase in wheat equivalent yield without increasing cultivation cost except lucerne seed cost. These results are closely related with the findings of Willey (1979) and Ofori \& Stern, (1987).

It is concluded that growing of wheat and lucerne as mixed crops by broadcasting @ 120 and $12 \mathrm{~kg} / \mathrm{ha}$, respectively produced maximum wheat grain and lucerne seed yield as well as straw yield of both the crops. Maximum net returns and $\mathrm{B}: \mathrm{C}$ ratio also obtained with same cropping system.

\section{References}

Ahmad, N. 1989. Studies on agro-economic relationship of component crops in lentil-wheat intercropping system, M.Sc. (Hons) Thesis, University of Agriculture, Faisalabad.

Akter, N., Alim, M.A., Islam, M.M., Naher, Z., Rahman, M. and Hossain, A.S.M. I. 2004. Evaluation of mixed and intercropping of lentil and wheat, Journal of Agronomy, 3 (1): 48-51.

Caballero, R., Goicoechea, E. L. and Hernaiz, P.J. 1995. Forage yields and quality of common vetch and oat sown at varying seeding ratios and seeding rates of common vetch, Field Crop Research 41: 135-140.

Chen, C., Westcott, M., Neill, K., Wichman, D and Knox, M. 2004. Row configuration and nitrogen application for barley-pea intercropping in Montana. Journal of Agronomy, 96(2004), pp. 1730-1738.

Çiftçi, V. and Ülker, M. 2005. Effect of mixed cropping lentil with wheat and barley at different seeding ratios, Journal of Agronomy 4(1):1-4.

Dhima, K.V., Lithourgidis, A.A., Vasilakoglou, I.B. and Dordas, C.A. 2007. Competition indices of common vetch and cereal intercrops in two seeding ratio, Field Crop Research 100: 249-256.

Mead, R. and Willey, R.W. 1980. The concept of a land equivalent ratio and advantages in yields for intercropping. Exp. Agric. 16: 217-228.

Ofori, F. and Stern, W.R. 1987. Cereallegume intercropping systems, Advances in Agronomy 41: 41-90. 
Singh, R.K. 1996. Nutrient management in wheat-lentil intercropping system under dry-land conditions, Lens News let, 23(1/2): 38-44.

Willey, R.W. 1979. Intercropping: Its importance and research needs, Part 1. Competition and yield advantages,
Field Crops Abstract 32:1-10.

Yagmur, M. and Kaydan, D. 2006. Different intercrop arrangement with lentils and barley under dryland condition, Pakistan Journal of Biological Sciences 9 (10):1917-1922.

\section{How to cite this article:}

Patel, A. S., M. S. Dabhi, K. J. Vihol, K. I. Patel, M. D. Patel and Patel, S. I. 2020. Efficient use of Resources by Wheat-Lucerne Mixed Cropping. Int.J.Curr.Microbiol.App.Sci. 9(08): 3652-3657. doi: https://doi.org/10.20546/ijcmas.2020.908.421 